\title{
Józef Stala (red.), Dzisiejszy bierzmowany. Problemy i wyzwania Wydawnictwo Jedność, Kielce 2005, ss. 512
}

Bierzmowanie należy do sakramentów inicjacji chrześcijańskiej i jest ściśle związane z sakramentem chrztu i Eucharystią. Chrzest włącza do Kościoła, a bierzmowanie dokonuje dalszego włączenia w Ciało Chrystusa oraz wzmacnia dynamizm łask chrzcielnych i obdarza szczególną mocą Ducha Świętego, który obdarza bierzmowanych niewysłowionym darem. Nadto bierzmowanie przygotowuje do podjęcia działalności apostolskiej, a także ściślej łączy z Kościołem, czyli zobowiązuje do szerzenia i obrony wiary słowem oraz czynem, a także do odpowiedzialności za Kościół. Stąd wynika konieczność przyjęcia sakramentu bierzmowania jako wyraz troski o rozwój łaski chrztu - ściślejsze złączenie chrześcijanina z Kościołem i otrzymanie szczególnej mocy Ducha Świętego, do stawania się rzeczywistym świadkiem Chrystusa wyznając wiarę nie tylko słowem, ale i czynem oraz broniąc jej w świecie. Chrześcijanie odrodzeni przez chrzest wzrastają w wierze i życiu chrześcijańskim mocą sakramentu bierzmowania, którego łaska stanowi nieodzowny składnik kościelnej tożsamości i warunkuje skuteczną realizację chrześcijańskiego powołania.

$\mathrm{Z}$ tych m.in. powodów należy zauważyć pracę zbiorową Dzisiejszy bierzmowany. Problemy i wyzwania powstałą pod redakcją ks. Józefa Stali i wydaną w Wydawnictwie „Jedność”. Omawiana książka to już kolejny, szósty tom, który ukazał się w serii „Dzisiaj.... Na stronie redakcyjnej została zamieszczona informacja, iż recenzję wydawniczą, której fragment został zamieszczony na okładce książki, przygotował ks. dr hab. Janusz Królikowski z Papieskiej Akademii Teologicznej w Krakowie (obecnie Uniwersytetu Papieskiego Jana Pawła II w Krakowie), który niejako scharakteryzował cel i uzasadnienie powstania niniejszej książki: „Opracowanie Dzisiejszy bierzmowany odznacza się interdyscyplinarnością i zaangażowaniem praktycznym. $Z$ tego względu jest ono jedynym tego typu opracowaniem $\mathrm{w}$ polskiej teologii... W wielu przypadkach praca odznacza się sformułowaniem trafnych postulatów pod adresem dalszych badań, zarówno w dziedzinie teologii, jak i formacji ludzkiej i kulturowej. Oznacza to, że może stać się pobudką do podjęcia dalszych prac badawczych. Wydaje się, że praca może zostać owocnie wykorzystana przez wszystkich, którzy zajmują się problematyką pedagogiczną i formacyjną. Jeśli chodzi o teologię, stanowi ona ważny wkład do podjęcia prac zmierzających do przygotowania adekwatnych programów formacyjnych prowadzących do przyjęcia sakramentu bierzmowania, a także - i to należy szczególne podkreślić - stanowi ważny punkt odniesienia do przygotowania katechizmu dla 
bierzmowanych, którego w Polsce wciąż brakuje. Omawiana praca zasługuje więc na zauważenie i wszechstronne poparcie, aby mogła dotrzeć do jak najszerszych kręgów formujących dzisiejszą młodzież”.

Recenzowana książka, oprócz Słowa wstępnego biskupa tarnowskiego, bp. Wiktora Skworca, zawiera jeszcze dwadzieścia pięć naukowych artykułów podzielonych na trzy części. Natomiast w zakończeniu książki zamieszczono streszczenie w trzech językach: angielskim, niemieckim i włoskim, co jest ułatwieniem dla obcojęzycznych poszukiwaczy zainteresowanych omawianym zagadnieniem. W części pierwszej Teologia zostało zamieszczonych siedem artykułów, w których podjęto zagadnienia biblijno-teologiczno-liturgicznych aspektów sakramentu bierzmowania, znaków i symboli bierzmowania, rozumienia bierzmowania jako sakramentu wtajemniczenia chrześcijańskiego, dojrzałości chrześcijańskiej i w świetle dokumentów synodalnych Kościoła w Polsce po 1980 roku. Natomiast w części drugiej Przygotowanie opublikowano dziewięć tekstów, w których omówiono proces przygotowania do bierzmowania, jego aspekty pastoralno-liturgiczne oraz wybrane podręczniki. Został także zaprezentowany obraz religijności młodzieży w świetle badań socjologicznych oraz problemy związane z wychowaniem młodzieży gimnazjalnej. Z kolei w ostatniej, części trzeciej Formacja znajdziemy dziewięć opracowań, w których scharakteryzowano młodzież gimnazjalną, rolę rodziny i świadka sakramentu bierzmowania, aspekty modlitewne, kreowanie postaw i wychowanie młodzieży, jak również znaczenie tańca oraz tendencji globalizacji. Z zaprezentowanej treści omawianej książki wyłania się zatem potrzeba głębokiego zrozumienia sakramentu bierzmowania, jak również odpowiedniego przygotowania do jego przyjęcia. $Z$ tego powodu najpierw potrzeba zgłębić teologię tego sakramentu, a także wypracować odpowiednie zrozumienie u kandydata do bierzmowania. Pomocą w tym celu jest właśnie formacja sakramentalna kandydatów do bierzmowania, która dokonuje się właśnie podczas nauczania religii w szkole i podczas katechezy parafialnej będącej pomocą w towarzyszeniu bierzmowanemu w realizowaniu jego misji w Kościele i w świecie.

Należy również podkreślić, iż w niniejszym opracowaniu zamieściło swoje teksty jakże wielu specjalistów. Wydaje się, iż publikację można uznać za dobrą pomoc w głębszym zrozumieniu sakramentu bierzmowania oraz ważności odpowiedniego przygotowania, formacji. $Z$ tego powodu recenzowana książka może stać się solidną pomocą zarówno dla katechetów i duszpasterzy przygotowujących młodzież do sakramentu bierzmowania, ale także i dla samych kandydatów do bierzmowania, którzy rzetelnie i odpowiedzialnie pragną przyjąć ten sakrament. Nadto może być również owocnie wykorzystana przez tych, którzy zajmują się problematyką pedagogiczną i formacyjną, bowiem mogą w niej znaleźć ważny wkład w podjęcie prac zmierzających do przygotowania odpowiednich programów formacyjnych pomagających kandydatom lepiej przygotować się do sakramentu bierzmowania. Podkreślił to także bp Wiktor Skworc w Słowie 
wstępnym: „Na tym ważnym polu formacji chrześcijańskiej młodego pokolenia cieszą wszystkie inicjatywy, które wyrastają z troski o pogłębione rozumienie i przeżywanie sakramentu bierzmowania. Do takich należy także przygotowana przez ks. Józefa Stalę publikacja Dzisiejszy bierzmowany. Problemy i wyzwania. Wyrażam nadzieję, że omówione w niej zagadnienia i realizacja wynikających z nich wniosków pastoralnych przyczynią się do tego, że wylanie darów Ducha Świętego, jakie dokonuje się w sakramencie bierzmowania, przyniesie bogate owoce w życiu bierzmowanych, a przez to przyczyni się do dobra Kościoła”'

Elżbieta Osewska

Uniwersytet Kardynała Stefana Wyszyńskiego

w Warszawie

1 Józef Stala (red.), Dzisiejszy bierzmowany. Problemy i wyzwania, Kielce 2005, s. 10-11. 